\title{
Örgütsel Stres ve İş Tatmini Arasında Psikolojik Dayanıklılığın Aracı Rolü: Akademisyenler Üzerine Bir Araştırma
}

\section{The Mediating Role of Resilience between Organizational Stress and Job Satisfaction: A Study on Academics}

Pınar Erdoğan ${ }^{a, *}$, Murat Ak ${ }^{b}$

${ }^{a}$ Dr. Öğretim Üyesi, Karamanoğlu Mehmetbey Üniversitesi, Uygulamalı Bilimler Yüksekokulu, 70200, Karaman/Türkiye. ORCID: 0000-0001-7817-1342

bDr., Öğretim Üyesi, Karamanoğlu Mehmetbey Üniversitesi, İktisadi ve İdari Bilimler Fakültesi, 70200, Karaman/Türkiye. ORCID: 0000-0003-2292-1444

\section{MAKALE BİLGİSİ}

Makale Geçmişi:

Başvuru tarihi: 02 Kasım 2020

Düzeltme tarihi: 02 Mart 2021

Kabul tarihi: 08 Mart 2021

Anahtar Kelimeler:

Örgütsel Stres,

Psikolojik Dayanıklılık,

İş Tatmini,

Akademisyen

A R T I C L E I N F O

\section{Article history:}

Received 02 November 2020

Received in revised 02 March 2021

Accepted : 08 March 2021

\section{Keywords:}

Organizational Stress,

Psychological Resilience,

Job Satisfaction,

Academician
ÖZ

$\mathrm{Bu}$ çalışmanın amacı örgütsel stresin iş tatminine etkisine psikolojik dayanıklılığın aracilık rolünün incelenmesidir. Çalışma kapsamında örgütsel stres ile iş tatmini ve psikolojik dayanıklılık ile iş tatmini ilişkileri de incelenmiştir. Çalışmada ilk olarak değişkenler arasındaki ilişkiyi araştıran çalışmalar incelenerek hipotezler oluşturulmuştur. Bir Devlet Üniversitesi'nde çalışan 261 akademisyenden anket tekniğiyle toplanan verilerle hipotezler test edilmiştir. Elde edilen verilerin yapısal geçerliliğini tespit etmek için keşfedici faktör analizi ve güvenilirlik analizi yapılmıștır. SPSS Process Makro programı aracılığıyla yapılan analizler sonucunda örgütsel stresin iş tatminini olumsuz yönde, psikolojik dayanıklılığın iş tatminini olumlu yönde etkilediği bulgulanmıştır. Ayrıca psikolojik dayanıklılığın iş tatmini üzerindeki dolaylı etkisinin anlamlı olduğu ve dolayısıyla da psikolojik dayanıklılığın örgütsel stres ile iş tatmini arasındaki ilişkiye yüksek düzeyde etki ile aracılık ettiği tespit edilmiștir.

\section{A B S T R A C T}

The objective of this study is to examine the mediating role of psychological resilience in the effect of organizational stress on job satisfaction. In the study, firstly, hypotheses were formed by examining the studies investigating the relationship between variables. Hypotheses were tested with the data collected by questionnaire technique from 261 academicians working at a state university. As a result of the analyzes made through the SPSS Process Macro program, it was found that organizational stress is negatively affected job satisfaction, and psychological resilience is positively affected job satisfaction. In addition, it was found that the indirect effect of psychological resilience on job satisfaction was significant, and thus, resilience mediated the relationship between organizational stress and job satisfaction with a high level of effect.

\section{Giriş}

Değişimin çok yoğun şekilde yaşandığı günümüz dünyasında faaliyet gösteren işletmeler değişime çok hızlı bir şekilde uyum sağlama baskısıyla karşı karşıyadır. Bu baskıyla en çok mücadele etmesi ve uyum sağlaması gereken işletme kaynaklarından bir tanesi hiç şüphesiz işletme çalışanlarıdır. $\mathrm{Bu}$ baskının beraberinde getirdiği örgütsel stres olgusu, tüm insanlığ hem sosyal hayatında hem de iş hayatında çepeçevre kuşatmış durumdadır ve işletmeler için yarattığı bütün olumsuz çıktılara rağmen tamamen önlenmesi ya da ortadan kaldırılması nerdeyse imkânsızdır. Örgütlerdeki çalışan beklentisiyle uyuşmayan nedenlerden ortaya çıkan örgütsel stres, hem bireysel hem de örgütsel düzlemde telafisi çok zor olumsuz sonuçlar ortaya çıkarabilmektedir. Örgütsel stresin neden olduğu olumsuz sonuçlardan biri çalıșanların yaşadı ğı iş tatminsizliğidir. İş tatmini çalışanın üyesi olduğu işletme ve yaptığı işi hakkındaki olumlu düşünceleridir ve bu düşünceler ne kadar çok olumluysa çalışanın iş tatmini de o oranda yüksektir.

\footnotetext{
*Sorumlu yazar/Corresponding author

e-posta: perdogan@kmu.edu.tr
} 
Örgütün gerek yapısal gerek de örgüt politikalarından hoşnut olunmaması örgütsel stresi artırmakta ve bireyi işinden soğutmaktadır. İşini sevmeyen bir çalışanın iş tatminin yüksek olması elbette ki pek mümkün değildir.

Psikolojik dayanıklılık bu çalışmada araştırılacak bir diğer değişkendir. Öncelikle fen bilimleri çalışmalarına, ardından psikoloji çalışmalarına konu olan psikolojik dayanıklılık kavramı örgütsel literatüre pozitif psikolojik sermaye şemsiyesi altında girmiştir. En genel manada; stresle ve sıkıntılı durumlarla iyi mücadele eden insanlar psikolojik olarak dayanıklı kişiler olarak ifade edilmektedir. Dolayısıyla bu kişilerin örgütsel kaynaklı stresten daha az etkilenmeleri nedeniyle iş tatmin düzeylerinin daha yüksek olması beklenen bir sonuçtur.

Yukarıdaki açıklamalar doğrultusunda bu araştırmada, "örgütsel stres, çalışanların iş tatmini ne düzeyde etkiler? çalışanın psikolojik dayanıklılığı iş tatmini ne düzeyde etkiler?, örgütsel stresin iş tatminine etkisinde psikolojik dayanıklılığın rolü var mıdır? gibi sorulara cevap aranmaya çalışılmıştır. Literatürde örgütsel stresin iş tatminine etkisinde psikolojik dayanıklılığın aracı rolünü inceleyen araştırmaya rastlanmamıştır. Bu bağlamda bu çalışmanın literatüre katkı sağlayacağı düşünülmektedir.

\section{Kavramsal Çerçeve}

\section{1.Örgütsel Stres Kavramı}

Latince kökenli bir kavram olan stres; kişilerde dengesizlik ve gerilim nedeni olarak gösterilen, güçlük, üzüntü anlamına gelen fiziksel veya psikolojik uyarıcıdır (Yılmazer, 2019: 197). Learners Dictionary tarafından kavram "kişinin hayatındaki sorunların neden olduğu zihinsel gerginlik ve endişe hali; güçlü endișe veya kaygı duygularına neden olan şey" (oxfordlearnersdictionaries. com) olarak tanımlanmıştır.

Günümüz koşullarında hemen hemen her yaş ve meslek grubunu etkileyen stres ilk kez 17. yy.da fizikçi Robert Hook tarafından kullanılmıştır (Yılmazer, 2019: 199). Tıp alanında ilk kez 1932-1934 yıllarında doktora öğrencisi Selye tarafından laboratuar hayvanlarının maruz kaldığı olumsuz koşulları tanımlamak için kullanılmıștır (Jackson, Ramsden ve Cantor, 2014: 24). Selye'nin 1936 tarihinde yayınlamış olduğu "adaptasyon ve hastalık" konulu makalesi stres literatüründe birincil referans kaynağı olduğundan, tarihçiler Selye'yi stresin yaratıcısı veya babası olarak kabul etmektedirler (Jackson vd., 2014: 22).

Selye tarafindan 1936 yılında ortaya atılan genel adaptasyon sendromunda -organizmanın kendini yeni koşullara adapte etme çabas1- (Jackson vd., 2014: 22-25) bedenin stresli durumlara verdiği tepki; alarm, direnme ve tükenme aşamaları olarak derecelendirilmiştir (Aytaç, 2009: 7; Erdoğan ve İraz, 2019: 117). Bireyin stresli olayla ilk karşılaştığı aşama alarm aşamasıdır. Bu aşamada bireyler telaşlı bir şekilde olayı nasıl çözeceğini düşünmektedir. Bu aşamada stres yükselmeye başlar (Ergeneli, 2017: 281). Direnç aşamasında organizma stresle mücadeleye başlayıp bitirdiği aşamadır. Eğer stresle başa çıkılamazsa bireyin stresle mücadele gücünü kaybettiği tükenme aşamasına geçilir (Zencirkıran ve Keser, 2018: 129).

Organizmanın fiziksel ve psikolojik sınırlarının zorlanmasıyla ortaya çıkan ve bu duruma karşı verilen fiziksel ve duygusal bir tepki olarak tanımlanabilen stres kavramının (Şimşek, Çelik, Akgemci ve Diken, 2020: 109) yönetim alanına girişi fizik, tıp, mühendislik bilimlerine göre daha geç olsa da örgütlerdeki verimlilik kaygısı, kavramın örgütsel araştırmalarda üst noktalara çıkmasına neden olmuştur (Aydın, 2004: 53). Stres, kişilerin fiziksel ve psikolojik sınırlarının zorlanmasıyla ortaya çıkan bir durum olduğuna göre örgütsel stresi; örgütsel kaynaklı olarak çalışanların psikolojik, fiziksel ve zihinsel zorlanmasına neden olan tepki şeklinde tanımlamak mümkündür (Zencirkıran ve Keser, 2018: 131).

Bireylerde strese neden olan üç faktörden (bireyin işi, kendisi, çevresi) biri olan örgütsel nedenler (Y1lmazer, 2019: 203) en fazla strese neden olan faktördür (Şimşek, vd., 2020: 109). Çok kapsamlı olan bu faktörler örgütün; politikaları, yapısal özellikleri, fiziki yapısı ve süreçleri altında sıralanabilecek çok farklı nedenlerden oluşmaktadır (Y1lmazer, 2019: 203). Örgütlerde stresin her dozu zararlı değildir ancak aşırı stres kişilere faydadan çok zarar vermektedir (Bozgeyikli, 2012). Stresin sonucunda bireylerde işe gelmeme, işten ayrılma, alkol ve uyuşturucu bağımlılığı, saldırganlık, sağlık sorunları ve bezginlik gibi sorunlar oluşabilmektedir (Şimşek, Çelik ve Akgemci, 2019: 233-235).

\section{2. İş Tatmini Kavramı}

İş tatmini 1930'lardan (Hawthorne Araştırmaları) itibaren hızla araştırılmaya başlanan ve günümüzde halen yoğun bir şekilde incelenmeye devam eden örgütsel davranış konularından biridir (Locke, 1969: 309; Kim, Tavitiyaman ve Kim, 2009: 374; Zencirkıran ve Keser, 2018: 102). Kavramın ilk resmi tanımı 1931 yılında Fisher ve Hanna tarafından "düzenleyici olmayan ruh hali eğiliminin bir ürünü” şeklinde yapılmıştır (Zhu, 2013: 293). Locke 1969 yılında iş tatminini, "kişininin iş değerlerine ulaşmayı başarması veya kolaylaştırması olarak işinin değerlendirilmesinden kaynaklanan zevkli duygusal durum" olarak tanımlarken 1974 yılında Churchill vd. Endüstriyel Satıcıların İş Memnuniyetini Ölçmek” başlıklı makalelerinde iş tatminin özelliklerini iş ve işle ilgili ortam özellikleri şeklinde belirtirken, işle ilgili durumları amirler, işler, iş arkadaşları, ücret ve terfi firsatları olarak belirtmişlerdir 1976 yılında ise Locke iş tatminini, "bir bireyin iş deneyimini değerlendirme sürecinde gelişen olumlu sevgi durumu" şeklinde tanımlamıştır (Zhu, 2013: 293-294).

İş tatmini çalışanın beklentileri ile iş uyumu sağlandığında gerçekleşen hoşnutluk halidir. $\mathrm{Bu}$ hoşnutluğun sağlanabilmesi için çalışanların örgütlerden pek çok beklentileri vardır. Bu beklentiler maddi, iş güvenliği, işin yapısı, terfi, kararlara katılım, iş ilişkileri, işletme politikaları ve yönetici ile ilgili beklentiler olup (Bingöl, 1997: 270-271) işyeri, çalışanın bu beklentilerini ne kadar çok karşılarsa iş tatmini o derece yükselmektedir.

En kısa şekliyle çalışanın işinden memnuniyet durumunu yansıtan iş tatminini artıran temel faktörler; işin çekiciliği, iletişim kurma firsatı, işteki özerklik, gelişme fırsatı, düzenli çalışma saati, esnek çalışma firsatı, iş güvencesi ve takdir edilme olarak belirtilirken kariyer ve terfi firsatlarının gittikçe azalması, çalışanların örgütten beklentilerinin sürekli, artması, daha bireyci kuşağın (y ve z) örgütlerde artması, iş dünyasındaki artan belirsizlik ise örgütlerde iş 
tatmini sağlamayı zorlaştıran nedenler (Zencirkıran ve Keser, 2018: 102-118).

İş tatmini örgütler için en önemli olumsuz sonucu çalışanın performans düşüşünün yaşanabileceği endişesi olmasına karşın iki kavram arasında her zaman doğrusal bir ilişki yoktur. Tatmin seviyesi düşük bir çalışanın iş performansı, iş tatmini yüksek bir çalışanın performansından daha yüksek olabilmektedir. Bazı çalışanların ise sadece daha az çalıştıkları zaman tatmin düzeyleri yüksek olabilmektedir (Şimşek vd., 2019: 192). Ancak uzun vadede performansın düşmesi, devamsızlık oranının yükselmesi,düşük yaşam tatmini, işgücü devir oranının yükselmesi, çalışanların sağlık ve olumsuz iş davranışında artış gibi olumsuz sonuçlar iş tatminsizliğini örgütler için mücadele edilmesi gereken bir sorun haline getirmektedir (Zencirkıran ve Keser, 2018: 118). Ayrıca bir örgütün çalışma koşulları ile ilgili en önemli geri bildirim mekanizması iş tatminidir. İş tatmini düşüklüğü işletme çalışma koşullarının bozulduğunu en önemli işaretidir (Y1lmazer, 2019: 284).

\subsection{Psikolojik Dayanıklılık Kavramı}

Psikolojik dayanıklılık kavramı ulusal literatürde yılmazlık, kendini toparlama gücü, psikolojik sağlamlık, dayanıklılık gibi farklı şekillerde çevrilmesine rağmen İngilizcede genellikle "resilience" olarak ifade edilmektedir (Basım ve Çetin, 2011: 107). Latince kökenli "resiliens" kökünden türeyen "resilience" kelimesi aslında fen bilimlerine ait bir kavramdır ve "gövdenin elastik modülü sayesinde deformasyonu takiben eski biçimini geri kazanması" olarak tanımlanmaktadır (Fletcher ve Sarkar, 2013: 4-5). Psikoloji biliminde ise dayanıklılık kavramı özellikle son 30 yılda incelenmeye başlanmıştır (Fletcher ve Sarkar, 2013: 18-19). Oxford Dictionary sözlükte kavram "zor koşullara hızla dayanıp bunlardan kurtulma" olarak tanımlanmaktadır (Fletcher ve Sarkar, 2013: 4-5). Literatürde referans kabul edilen bazı psikolojik dayanıklılık tanımları (Fletcher ve Sarkar, 2013) şöyledir:

$\checkmark$ Dayanıkl11ık, zorlu veya tehdit edici koşullara rağmen başarılı bir adaptasyon sürecini, kapasitesini veya sonucunu ifade eder (Masten, Best ve Garmezy, 1990: 426).

$\checkmark$ Zorluklar karşısında kişinin gelişmesini sağlayan kişisel nitelikler (Connor ve Davidson, 2003: 76).

$\checkmark$ Uyum veya gelişime yönelik ciddi tehditlere rağmen iyi sonuçlarla karakterize edilen bir fenomen sınıfı (Masten, 2001: 228).

Tanımlarda görüldüğü gibi psikolojik dayanıklılık kavramı araştırmacılar tarafindan farklı şekillerde tanımlanmış olsa da tanımların ortak noktası bireye sıkıntı verecek bir olayın olması ve bu olaya olumlu adaptasyon sürecidir. Yapılan araştırmalara (Rodriguez vd., 2015) göre psikolojik yönden dayanıklı olan bireylerin yaşadıkları problemleri çözmede daha fazla strateji geliştirdiğini ortaya koymaktadır. Her yeni yaşanılan problem ise kişinin öğrenmesini ve psikolojik dayanıklılık düzeyinin daha da artmasına neden olmaktadır (Sarıkaya, 2019: 15).

Sıkıntılı bir durumun üstesinden gelme ya da stresle başa çıkma sürecini ifade eden psikolojik dayanıklılık çalışmaları büyük ölçüde gelişimsel psikoloji alanına dayanmaktadır (Meredith vd., 2011: 1-2). 1970'lerde, bir grup öncü bilim adamının (psikolog ve psikiyatrist) dikkatini psikopatoloji riski taşıyan çocuklarda dayanıklılık konusunun çekmeye başlamasıyla araştırmalar başlamıştır (Masten, 2001: 227). $\mathrm{Bu}$ öncül araştırmacılar tarafından yapılan araştırma sonuçları, aşırı yoksulluk ve diğer olumsuz koşullarda büyümüş olmalarına rağmen bazı çocukların şaşırtıcı derecede normal gelişim gösterdiklerini bulgulamışlardır (Meredith vd., 2011: 1-2). Dirençli çocuklar olarak nitelendirilen bu çocukların yaşamlarındaki farklılıklar ortaya konulmaya çalışılmıştır (Masten, 2001: 227). Bilimsel çalışmalarda ilk düşünce "yenilmez" olarak adlandırılan bu çocukların farklı bir özellik taşıdıkları üzerine olmuştur (Masten, 2001: 227). Ancak zaman içinde psikolojik dayanıklılığın doğuştan gelen değil öğrenilebilir bir kişisel özellik olduğu ve bu özelliği de karşı karşıya kalınan durumların geliştirdiği kabul edilmiştir (Basım ve Çetin, 2011: 105). Dayanıklı kişileri diğer insanlardan ayıran üç özellik gerçekliği kabul etmeleri, hayatın anlamlı olduğu konusunda derin bir inanca sahip olmaları ve değişikliklere hızlı uyum becerisine sahip olmalarıdır (Luthans ve Youssef, 2004:154). Bu özellikleri yaşadıkları olaylar neticesinde geliştirebilen insanlar psikolojik yönden daha güçlü olabileceklerdir.

Bazı bireylerin, neden daha iyi yaşanılan baskılara dayanabildiklerini anlamaya çalışan psikolojik dayanıklılık çalışmaları, önceleri kişilerde psiko-sosyal sorunlara yol açan risk faktörlerine yoğunlaşmış ancak 1990'ların başından itibaren risk faktörlerinden bireyin güçlü yönlerinin belirlenmesine doğru bir paradigma kayması yaşanmıştır (Fletcher ve Sarkar, 2013: 3). Bireyin güçlü yönlerine odaklanılmasıyla birlikte psikolojik dayanıklılık, pozitif psikolojinin içinde yer alan kavramlardan biri haline gelmiş (Turan Sarkaya, 2019: 14) ancak pozitif psikolojinin örgütsel davranışa uygulanmasıyla oluşan olan pozitif örgütsel davranış alanına dahil edilmemiştir (Erdoğan ve İraz, 2019; Urgan ve Sevim, 2019; Luthans, 2002). Oysa Luthans'a (2002: 702) göre psikolojik dayanıklılık liderlerin ve çalışanların karşı karşıya bulunduğu örgütsel iç ortamla son derece ilgilidir ve pozitif örgütsel davranış kriterlerine iyi uyum sağlamaktadır. Psikolojik dayanıklılığın sadece birkaç kişinin sahip olduğu olağanüstü, özel bir hediye olduğu düşünülürken günümüzde artık sıradan insanların gündelik büyüsünden ileri gelen bir özellik olduğunun kabul edilmiştir (Luthans, 2002; Erdoğan ve İraz, 2020). Psikolojik dayanıklılığın her insanda görülebilir olmasının örgütler için muazzam etkileri olacağını belirten Luthan's (2002: 702) pozitif örgütsel davranış açısından esas zorluğun çalışanlarda dayanıklılığı daha iyi anlama ve ardından bu potansiyellerini açığa çıkarma noktasında olduğunu belirtmektedir.

\section{Yöntem}

\subsection{Araştırmanın Hipotezleri ve Modeli}

Örgütlerde stres bireysel ve örgütsel düzlemde pek çok yıkıcı soruna yol açabilmektedir. Stres düzeyi yüksek çalışanlar zihinsel ve psikolojik olarak etkilenmekte ve bu durum çalışanın performans düşüklüğüne, iş heyecanını kaybetmesine, heyecanının kaybedilmesi ise iş tatmininin azalmasına yol açabilmektedir. Nitekim düşük is stresi iş tatminini artıran bir etken olarak karşımıza çıkmaktadır (Zencirkıran ve Keser, 2018: 103). Yapılan ampirik çalışmalarda da iki kavram arasında beklenti doğrultusunda sonuçlar elde edilmiştir. Bu çalışmalar genellikle örgütsel 
stres ve ş tatmini arasında negatif ilişkili olduğunu göstermektedir (Hollona ve Chesser, 1976; Arslan, 2010). Örneğin Emiroğlu, Akova ve Tanrıverdi (2015) otel işletmelerinde yaptıkları araştırmalarında çalışanların iş stres düzeyleri ile iş tatminleri arasında negatif yönlü, iş stresi ile işten ayrılma niyeti arasında ise pozitif yönlü anlamlı ilişki olduğu bulgusunu elde etmişler ve bu sonuç doğrultusunda iş stresinin çalışanlarının iş tatminlerini düşmesine neden olduğu ve işten ayrılmaları artırdığını ileri sürmüşlerdir. Kahraman (2019) Milona'daki Türk KOBİ yöneticileri örneklemi ile yaptığ 1 tez çalışmasında yine stres il iş tatmini arasında negatif anlamlı ilişki bulgulamıştır. Ajayi ve Abimbola (2013) ulusal petrol yatırım yönetimi hizmetlerindeki 225 çalışan ile yaptığı çalışmada Tyson ve Aggarwal (2002) hemşireler ile yaptığı çalışma sonucunda örgütsel stres artıkça iş tatminin azaldığ 1 ve çalışan performansının düştüğü bulgulamışlardır.

Psikolojik dayanıklılık ise yukarıda da belirtildiği gibi sıkıntılı bir durumun üstesinden gelme ya da stresle başa çıkma sürecini ifade eden bir kavramdır. Psikolojik dayanıklılık kavramın özünde zaten stresli durumlarla mücadele durumu vardır ve stres ile daha iyi mücadele edenler psikolojik olarak daha dayanıklı olarak düşünülmektedir. Stresle iyi başa çıkabilen çalışanlarında iş tatmini düzeyi bu doğrultuda yüksek olacaktır. Dolayısıyla örgütlerde stres seviyesi psikolojik yönden dayanıklı olan çalışanları daha az etkileyecek, stresten daha az etkilenen çalışanların iş tatmin seviyeleri daha yüksek olacaktır. Yani örgütsel stresin iş tatmini üzerindeki olumsuz etkisinde psikolojik dayanıklılığın aracılık rolü üstlenmesi beklenmektedir. $\mathrm{Bu}$ doğrultuda aşağıdaki hipotezler oluşturulmuştur:

H1: Örgütsel stres düzeyleri akademisyenlerin iş tatminlerini olumsuz yönde etkiler.

H2: Örgütsel stres akademisyenlerin psikolojik dayanıklılığını olumsuz yönde etkiler.

H3. Psikolojik dayanıklılık akademisyenlerin iş tatminini olumlu yönde etkiler.

H4: Örgütsel stres ve iş tatmini arasındaki ilişkide psikolojik dayanıklılığın aracı rolü vardır. Yukarda belirttiğimiz hipotezler doğrultusunda araştırma modeli oluşturulmuş ve Şekil 1'de sunulmuştur.

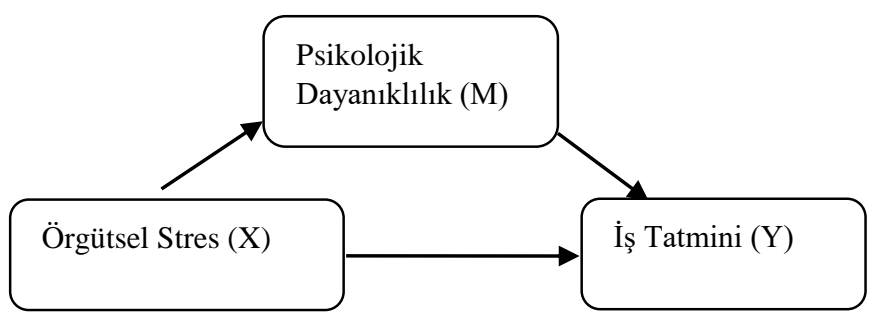

Şekil 1: Test Edilecek Aracılık Modeli

\subsection{Araştırmanın Amacı, Evren ve Örneklemi}

$\mathrm{Bu}$ araştırmanın amacı araştırmada örgütsel stresin iş tatmin düzeyine etkisinde psikolojik dayanıklılığın aracı rolünü belirlemektir. Ayrıca araştırmada örgütsel stresin akademisyenlerin psikolojik dayanıklılıkları ve iş tatmin düzeyine etkisi belirlenmeye çalışılmıştır. $\mathrm{Bu}$ amaçlar doğrultusunda bu çalışmanın evrenini bir devlet üniversitesinde görev yapan akademisyenler oluşturmaktadır. İlgili üniversitenin Bilimsel Araştırma ve Yayın Etik Kurulundan 06.07.2020 tarih ve 14490 sayılı yazısıyla izin alınmıştır. Üniversitede 2020 yılı performans programı verilerine göre 2019 yılında 668 akademisyen görev yapmaktadır. Araştırma evreninden \%95 güven düzeyinde $\% 5$ 'lik hata ile yeterli örneklem büyüklüğü 244 olarak belirlenmiştir (www.surveysystem.com/sscale). Dolayısıyla örneklem bu çalışmadaki örneklem büyüklüğü olan 261 evreni temsil edecek büyüklüktedir.

\section{3.Ölçekler}

Araştırmada akademisyenlerin örgütsel stres, psikolojik dayanıklılık ve iş tatmini düzeyini belirlemede geçerlilikleri ve güvenilirlikleri test edilmiş ölçüm araçları seçilmiştir. Çalışmada kullanılan örgütsel stres ölçeği Theorell vd. (1988) tarafından geliştirilen Yıldırım, Taşmektepligil ve Üzüm (2011) tarafindan uyarlanan 17 madde ve 4 boyuttan oluşan ölçektir. 5'li Likert tarzındaki ölçeğin güvenirliği Yıldırım vd. (2016) tarafından 0,79 olarak hesaplanmıştır. Çalışmada kullanılan iş tatmini ölçeği Hackman ve Oldhamn'a (1975) ait iş özellikleri anket'inden Basım ve Şeşen (2009) tarafından uyarlanan tek boyutlu 5 maddeli, 5'li Likert tarzında bir ölçektir. Ölçeğin toplam güvenilirliği Basım ve Şeşen tarafından 0,78 olarak hesaplanmıştır. Çalışmada kullanılan Psikolojik Dayanıklılık Ölçeği, Işık (2016) tarafından geliştirilmiştir. Ölçek 21 madde ve 3 alt boyuttan oluşmaktadır. 5'li Likert tarzındaki ölçeğin güvenirliği Işık (2016) tarafından 0,76 olarak hesaplanmıştır.

\subsection{Verilerin Analizi}

Araştırmada elde edilen verilerin analizinde SPSS programının 22. Versiyonu kullanılmıştır. Ölçeklerin geçerlilik ve güvenilirliklerini ortaya koymak için keşfedici faktör analizi ve güvenirlik analizi yapılmıştır. Araştırmanın hipotezleri Hayes tarafından geliştirilen Process Macro (SPSS için) programı kullanılarak analiz edilmiş ve elde edilen sonuçların yorumlanmasında Bootstrapping tekniği kullanılmıştır. Bootstrapping tekniğinde hesaplamalar orijinal verilerdeki gözlemler tekrarlanarak oluşturulan yeni gözlem seti ile yapılmaktadır (Gürbüz, 2019: 56).

\section{Bulgular}

\subsection{Demografik Bulgular}

Araştırma örnekleminde yer alan 261 akademisyene ilişkin demografik veriler Tablo 1'de sunulmuştur. 
Tablo 1: Akademisyenlere İlişkin Demografik Veriler

\begin{tabular}{|c|c|c|c|}
\hline Değișken & Kategori & Frekans & $(\%)$ \\
\hline \multirow{2}{*}{ Cinsiyet } & Kadın & 102 & 39,1 \\
\hline & Erkek & 159 & 60,9 \\
\hline \multirow{5}{*}{ Unvan } & Prof. & 17 & 6,5 \\
\hline & Doçent & 25 & 9,6 \\
\hline & Dr.Öğr.Üyesi & 67 & 25,7 \\
\hline & Öğretim Grv. & 75 & 28,7 \\
\hline & Araş. Grv. & 77 & 29,5 \\
\hline \multirow{2}{*}{ İdari görev } & Var & 86 & 33,0 \\
\hline & Yok & 175 & 67,0 \\
\hline \multirow{5}{*}{$\begin{array}{l}\text { Kurumda } \\
\text { Çalışma Süresi }\end{array}$} & $1-5 \quad \mathrm{y} 1 \mathrm{l}$ & 114 & 43,7 \\
\hline & 6-10 y1l & 73 & 28,0 \\
\hline & $11-15$ y1l & 38 & 14,6 \\
\hline & $16-20 \mathrm{y} 1 \mathrm{l}$ & 17 & 6,5 \\
\hline & 21 ve üzeri & 19 & 7,3 \\
\hline \multirow{5}{*}{$\begin{array}{l}\text { Toplam İş } \\
\text { Tecrübesi }\end{array}$} & $1-5$ y1l & 56 & 21,5 \\
\hline & $6-10 \mathrm{y} 11$ & 62 & 23,8 \\
\hline & $11-15$ y1l & 58 & 22,2 \\
\hline & $16-20 \mathrm{y} 11$ & 45 & 17,2 \\
\hline & 21 ve üzeri & 40 & 15,3 \\
\hline Toplam & Akademisyen & 261 & 100 \\
\hline
\end{tabular}

Tablo 1'e göre katılımciların \%60,9 'u erkek, \%39,1'i kadındır. Unvanlarına göre en fazla katılımcı araştırma görevlileridir (\%29,5). Katılımcıların \%67'sinin herhangi bir idari görevi bulunmamaktadır. Katılımcıların \%43,7'si kurumda 1-5 yıl arasında bulunurken, toplam iş tecrübesi açısından en yüksek oran $(\% 23,8)$ 6-10 y1l arasında çalışanlara aittir.

\section{2.Ölçeklere İlişkin Normallik, Geçerlik ve Güvenirlik Analizleri}

Araştırmada kullanılan ölçeklerin yap1 geçerliliğinin kontrolü keşfedici faktör analizi (KFA) ile yapılmıștır. Keşfedici faktör analizi yap1 geçerliliğini test etmede kullanılan yaygın bir tekniktir (Çokluk, Şekercioğlu ve Büyüköztürk, 2016: 185). Keşfedici faktör analizi uygulanması için ön koşullardan biri değişkenlerin normal dağ 1 lım göstermesidir (Gürbüz ve Şahin, 2018: 319). Bu sebeple faktör analizinden önce verilerin normal dağılıp dağılmadığı test edilmiştir. Normallik analizi sonuçlarına göre örgütsel stres (çarpıklık değeri: 0,103 , sh $=0,100$ ve basıklık değeri:0,356, sh=0,270), iş tatmini (çarpıklık değeri: $-0,579, \mathrm{sh}=0,151$; ve basılklı değeri :-0,301, sh=0,205) ve psikolojik dayanıklılık (çarpıklık değeri $=-0,193, \mathrm{sh}=0,120$ ve basıklık değeri $=0,449, \mathrm{sh}=0,300)$ ölçeklerinin çarpıklık ve basıklık değerleri -1 ve +1 arasında yer aldığ verilerin normal dağıldığı varsayılmıştır (Ak, 2010: 73).

Normallik varsayımının karşılanmasının ardından ölçeklerin yap1 geçerliliğinin test edilmesi aşamasına geçilmiştir. Keşfedici faktör analizinde örneklem yeterliliği için KMO değerinin 0,60'tan büyük olması, Barlett Küresellik Testinin ise anlamlı olması $(\mathrm{p}<0,05)$ referans olarak alınmıştır (Gürbüz ve Şahin, 2018: 319).

Örgütsel stres ölçeğine temel bileşenler analizi (principalcomponent) ve varimax eksen döndürmesi tekniği kullanılarak yapılan Keşfedici Faktör Analizi sonucunda Kaiser-Meyer-Olkin (KMO) örneklem yeterlilik değerinin $0,736(<0,60)$ olması nedeniyle örneklem büyüklügünün faktör analizi için yeterli olduğu tespit edilmiştir (Gürbüz ve Şahin,2018: 330). Barlett küresellik testinin anlamlı olması $\left(\mathrm{X}^{2}(78)=1244,551 \mathrm{p}<.001\right)$ maddeler arasinda korelasyon ilişkilerinin faktör analizi için uygun olduğuna işaret etmektedir (Gürbüz ve Şahin,2018: 330). KFA' da özdeğerlerin 1'den büyük olması durumunda faktörlerin oluşması sağlanmıştır.

Araştırmada örgütsel stresi ölçmek için kullanılan 17 maddeden oluşan ölçek için yapılan KFA analizi sonucunda 4, 5 ve 9. maddeler düşük faktör yükü, 6. madde ise düşük güvenilirlik nedeniyle ölçekten çıkarılmıştır. Elde edilen 4 faktörlü sonucu, yamaç serpinti grafiği desteklemektedir. KFA sonucunda 13 maddelik ölçeğin 4 faktörlü yapıda olduğu, faktörlerin toplam varyansın \%66,332'sini açıkladığı ve maddelerin faktör yüklerinin ,400'ün üzerinde olduğu bulgulanmıştır. Araştırma bulgularına göre, ölçeğin açıkladığı varyansın $(\% 66,332) \% 50$ 'den yüksek olması nedeniyle (Gürbüz ve Şahin, 2018: 321) ölçtüğü niteliği yeterince açıkladığ 1 gözlenmiştir. Tablo 2'de de görüleceği üzere tüm faktörlerin Cronbach's Alpha güvenilirlik katsayıları 0,70'ten büyüktür. Ayrıca tüm ölçeğin Cronbach's Alpha değeri 0,776 olarak bulunmuştur

Tablo 2. Örgütsel Stres Ölçeğine İlişkin Faktör Analizi Sonuçları

\begin{tabular}{|c|c|c|c|c|c|}
\hline Madde & $\begin{array}{l}\text { Sosyal } \\
\text { destek }\end{array}$ & $\begin{array}{l}\text { İş } \\
\text { yükü }\end{array}$ & $\begin{array}{l}\text { Karar } \\
\text { verme }\end{array}$ & $\begin{array}{l}\text { Bece } \\
\text { ri } \\
\text { kulla } \\
\text { nimı }\end{array}$ & $\alpha$ \\
\hline Madde 17. & ,850 & & & & \\
\hline Madde 13. & ,792 & & & & ,829 \\
\hline Madde 14. & ,778 & & & & \\
\hline Madde 15. & ,750 & & & & \\
\hline Madde 16. &, 597 & & & & \\
\hline Madde 2. & & ,888 & & & \\
\hline Madde 1. & & 841 & & & ,750 \\
\hline Madde 3. & & 666 & & & \\
\hline Madde 11. & & & ,894 & & \\
\hline Madde 10. & & & 853 & & ,734 \\
\hline Madde 12. & & & ,493 & & \\
\hline Madde 7. & & & &, 854 & \\
\hline Madde 8. & & & &, 755 & ,720 \\
\hline Özdeğer & 4,007 & 2,061 & 1,466 & 1,089 & \\
\hline $\begin{array}{l}\text { Açıklanan } \\
\text { varyans } \\
\text { Yüzdesi }\end{array}$ & 30,825 & 15,857 & 11,274 & 8,376 & \\
\hline \multicolumn{6}{|c|}{ Toplam açıklanan varyans yüzdesi $\quad 66,32$} \\
\hline \multicolumn{6}{|c|}{ KMO: 0,736; BKT:1244,551 ; p: $0,000<0,001$} \\
\hline
\end{tabular}

Algılanan iş tatmini ölçeğinin Kaiser-Meyer-Olkin (KMO) örneklem yeterlilik değerinin 0,860 olması ve Barlett küresellik testinin anlamlı olması $\left(\mathrm{X}^{2}(10)=763,311 \mathrm{p}<.001\right)$ örneklem sayısının yeterli olduğu ve maddeler arasında korelasyon ilişkilerinin faktör analizi için uygun olduğuna işaret etmektedir (Gürbüz ve Şahin, 2018: 330). İş Tatmini ölçeğine yapılan faktör analizi sonucunda ölçeğin tek faktörlü yapıda olduğu tespit edilmiştir. KFA sonucunda 5 maddelik ölçeğin tek faktörlü yapısının toplam varyansın \%69,407 'sini açıkladığı ve maddelerin faktör yüklerinin0 ,7'nin üzerinde olduğu bulgulanmıştır. Ölçeğin açıkladığı varyans $(\% 69,407)$ ölçtüğü niteliği yeterince açıkladığı anlamına gelmektedir. Tek faktörlü iş tatmini ölçeğinin Cronbach's Alpha güvenilirlik katsayısı 0,883 olarak bulgulanmıştır. İş tatmini ölçeğine ait KFA sonuçları Tablo 3 'te gösterilmektedir. 
Tablo 3. İş Tatmini Ölçeğine İlişkin Faktör Analizi Sonuçları

\begin{tabular}{|c|c|c|}
\hline Madde & $\begin{array}{l}\text { İş } \\
\text { Tatmini }\end{array}$ & $\alpha$ \\
\hline $\begin{array}{l}\text { Madde } 4 . \\
\text { Madde } 5 . \\
\text { Madde } 2 . \\
\text { Madde } 3 . \\
\text { Madde1. }\end{array}$ & $\begin{array}{l}, 921 \\
, 885 \\
, 814 \\
, 774 \\
, 760\end{array}$ &, 883 \\
\hline \multicolumn{3}{|l|}{ Özdeğer: 3,470} \\
\hline \multicolumn{3}{|c|}{ Açıklanan varyans yüzdesi: 69,407} \\
\hline \multicolumn{3}{|c|}{ Toplam açıklana varyans yüzdesi : 69,407} \\
\hline \multicolumn{3}{|c|}{ KMO:0 ,860; Barlett Küresellik Testi:763,311; p: ,000<0,01 } \\
\hline
\end{tabular}

Son olarak psikolojik dayanıklılık ölçeğine KFA yapılmıștır. Psikolojik dayanıklılık ölçeğinin KMO örneklem yeterlilik değerinin ,850 olması ve Barlett küresellik testinin anlamlı olması $\left(\mathrm{X}^{2}(190)=1711,506 \mathrm{p}<0,001\right)$ örneklem sayısının yeterli olduğu ve maddeler arasında korelasyon ilişkilerinin faktör analizi için uygun olduğuna işaret etmektedir. Psikolojik dayanıklılık ölçeğine yapılan faktör analizi sonucunda ölçeğin dört faktörlü yapıda olduğu tespit edilmiştir. KFA analizi sonucunda 15. madde düşük faktör yükü nedeniyle ölçekten çıkarılmıştır. KFA sonucunda 20 maddelik ölçeğin dört faktörlü yapısının toplam varyansın \%53,626'sını açıkladığı ve maddelerin faktör yüklerinin 0,400'ün üzerinde olduğu bulgulanmıştır. Ölçeğin açıkladığ varyansın $(\% 53,626)$ ölçtüğü niteliği yeterince açıkladığı anlamın gelmektedir. Dört faktörlü psikolojik dayanıklılık ölçeğinin Cronbach's Alpha güvenilirlik katsayısı ,865 olarak bulgulanmıştır. Psikolojik dayanıklılık ölçeğine ait KFA sonuçları Tablo 4'te gösterilmektedir.

Tablo 4. Psikolojik Dayanıklılık Ölçeğine İlişkin Faktör Analizi Sonuçları

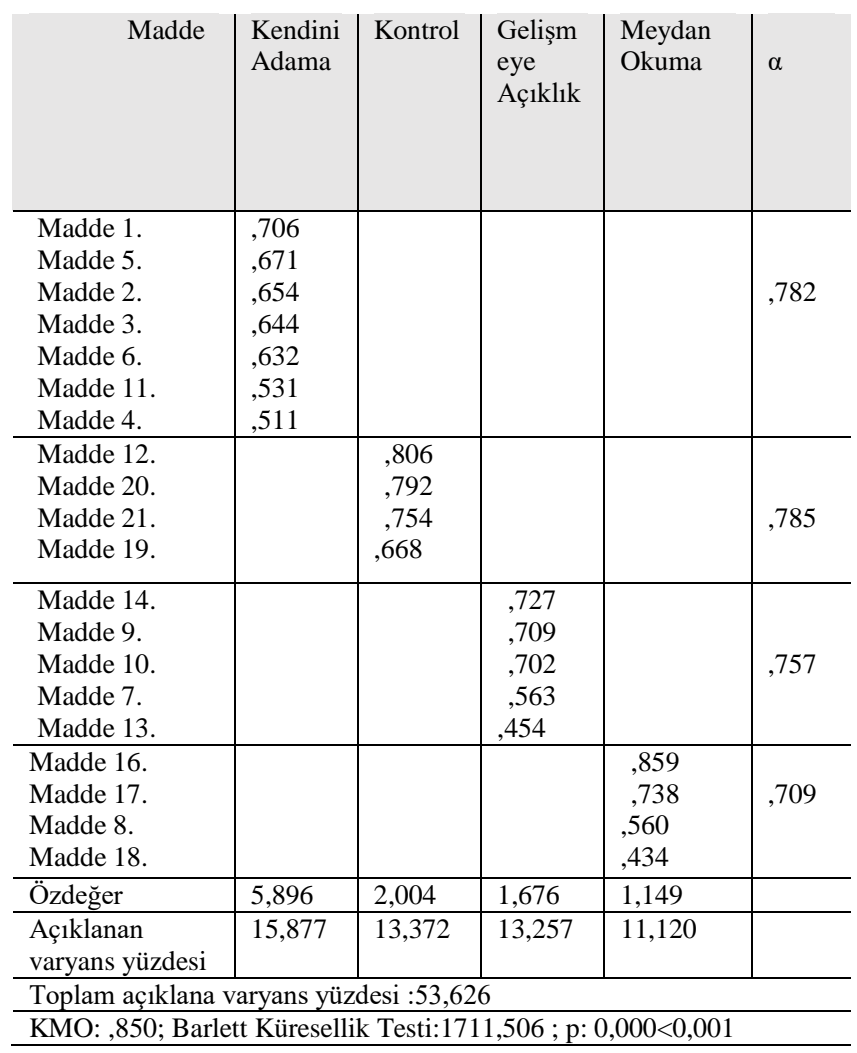

\subsection{Hipotez Testleri}

Aracılık modelinin analizinde Baron ve Kenny yöntemine (geleneksel yaklaşım) getirilen eleştiriler neticesinde ileri sürülen çağdaş yaklaşım referans alınmıştır (Gürbüz, 2019). Aracılık analizlerinde dolaylı etki değerlerin hesaplanması ve bu değerlerden çıkarımlar yapılması çağdaş yaklaşımın odak noktasıdır. Dolaylı etki "a yolu" ile "b yolu" nun çarpılması ile bulunur. a yolu bağımsız değişkenin (X), aracı değişken (M) üzerindeki etkisi, b yolu ise aracı değişkenin (M) sonuç değişkeni (Y) üzerindeki etkisidir. Dolaylı etkinin anlamlı olması (a.b sonucunun bootstrap testi sonucuna göre) durumunda aracılık modeli doğrulanmış kabul edilecek, başka bir test yapılmayacaktır (Gürbüz, 2019: 55). Çağdaş yaklaşımın varsayımları şunlardır (Gürbüz, 2019: 55):

$\checkmark \mathrm{X}^{\prime}$ in $\mathrm{Y}^{\prime}$ ye etkisi olan toplam etkinin istatistiksel olarak anlamlı olması zorunlu değildir.

$\checkmark$ X'in M' ye etkisinin (a yolu) istatistiksel olarak anlamlı olması zorunlu değildir.

$\checkmark$ M kontrol edilirken $X^{\prime}$ in $Y^{\prime}$ ye etkisinin ( $c^{\prime}$ yolu) tek başına anlamlı olması zorunlu değildir.

$\checkmark$ Kısmi ve tam aracılık kavramları yerine doğrudan etki (c'), dolaylı etki (a.b.) ve toplam etkinin $\left(c=c^{\prime}+a b\right)$ raporlanması daha bilimseldir.

$\mathrm{Bu}$ varsayımlar doğrultusunda örgütsel stresin akademisyenlerin iş tatminlerine etkisinde psikolojik dayanıklılığın aracılık rolü olup olmadığını test etmek amaciyla bootstrap yöntemini esas alan regresyon analizi yapılmıştır. Bootstrap yönteminin, Baron ve Kenny' nin (1986) geleneksel yönteminden ve Sobel testinden daha güvenilir sonuçlar verdiği öne sürülmektedir (Gürbüz, 2019). Analizlerde bootstrap tekniği ile 5000 yeniden örneklem seçeneği tercih edilmiştir. Bootstrap tekniği ile yapılan aracılık etki analizlerinde, araştırma hipotezinin desteklenebilmesi için analiz neticesinde elde edilen \%95 güven aralığındaki değerlerin sıfır (0) değerini kapsamaması gerekmektedir. $\mathrm{Bu}$ doğrultuda yapılan regresyon analizi sonuçları Tablo 5 'te paylaşılmıştır.

Tablo 5.Değişkenlere İlişkin Regresyon Analizi Sonuçları ( $\mathrm{n}=261)$

\begin{tabular}{|c|c|c|c|c|}
\hline \multicolumn{5}{|c|}{ Sonuç Değişkenleri } \\
\hline & $M(\mathrm{P}$. Dayanıklılık) & & $Y(\dot{\mathrm{I}} \mathrm{s} \mathrm{T}$ & tmini) \\
\hline $\begin{array}{l}\text { Tahmin } \\
\text { Değişkenleri }\end{array}$ & S.H. & & $b$ & S.H. \\
\hline $\begin{array}{c}\mathrm{X} \\
\text { (Örgütsel Stres) }\end{array}$ & $a-, 388 * * * \quad, 060$ & $c^{\prime}$ &,- 177 &, 116 \\
\hline \begin{tabular}{l}
\multicolumn{1}{c}{$\mathrm{M}$} \\
(Psikolojik \\
Dayanıklılık)
\end{tabular} & & $b$ & $1,303 * * *$ &, 112 \\
\hline \multirow[t]{2}{*}{ Sabit } & $\dot{\mathrm{IM}}, 5,066$ & $\overline{\mathrm{IIY}}$ & $-1,075$ & ,645 \\
\hline & $\begin{array}{l}\mathrm{R}^{2}=, 140 \\
\mathrm{~F}(1 ; 259)=42,133 \\
\mathrm{p}=, 000<, 001\end{array}$ & $\begin{array}{r}\mathrm{R}^{2}= \\
(2 ; 2 \\
\mathrm{p}=\end{array}$ & $\begin{array}{l}404 \\
8) 87,57= \\
00<, 001\end{array}$ & \\
\hline
\end{tabular}

Not. $* p<, 05 ; * * p<, 01 ; * * * p<, 001 ; \quad$ S.H.: Standart Hata, Standardize edilmemiş beta katsayıları (b) raporlanmıştır.

Tablo 5'e göre örgütsel stres psikolojik dayanıklılığı (a yolu) anlamlı düzeyde negatif yönde etkilemektedir $(b=-0,388$; $\% 95 C I \quad[-, 5054 ;-0,270 ; \quad t=-6,4910 ; \mathrm{p}: 0,000<0,001)$. Örgütsel stresin psikolojik dayanıklılığa etkisini gösteren $b$ (standardize olmayan beta) değerinin anlamlı olduğu hem $\mathrm{p}$ değerinin ,001'den küçük olmasından hem de CI 
değerlerinin $0 \quad$ (sıfır) değerini kapsamamasından anlaşılmaktadır. $\mathrm{Bu}$ sonuca göre örgütsel stres psikolojik dayanıklılıktaki değişimin yaklaşık \%14'ünü açıklamaktadır.

Aracı değişkenimiz olan psikolojik dayanıklılığın iş tatminine etkisi (b yolu) istatistiksel olarak anlamlı ve olumlu yönde bulgulanmıştır $(b=1,303 ; \% 95$ CI [1,0822; $1,5248] ; \quad \mathrm{t}=11,6209 ; \mathrm{p}: 0,000<, 001)$. Örgütsel stresin psikolojik dayanıklılık (c' yolu= doğrudan etki) ile birlikte regresyona dahil edildiği zaman bulgulanan doğrudan etki değeri istatistiksel olarak anlamlı bulgulanmamıştır $\left(\mathrm{c}^{\prime}=\right.$ , $177 ; \% 95$ CI [ -0,4062;0,0515]; $\mathrm{t}=-1,5258 ; \mathrm{p}: 0,128$ $>, 05)$.Aracı değişkenimiz olan psikolojik dayanıklılığın olmadığ 1 bir modelde örgütsel stresin iş tatmini üzerindeki etki değeri (c yolu=toplam etki) istatistiksel olarak anlamlı ve negatif yönde bulgulanmıştır $\left(\mathrm{c}=-, 682 ; \mathrm{R}^{2}=0,093 ; \mathrm{t}=-\right.$ 5,140; p: $0,000<0,001)$.

Son olarak psikolojik dayanıklılı̆̆ın iş tatminine dolaylı etkisinin anlamlı olup olmadığı Bootstrap yöntemi ile elde edilen güven aralıklarına göre tespit edilmiştir. Bootstrap tekniği ile yapılan aracılık etki analizlerinde, araştırma hipotezinin desteklenebilmesi için analiz neticesinde elde edilen \%95 güven aralığındaki değerlerin sıfır (0) değerini kapsamaması gerekmektedir. Sonuçlar Tablo 6' da gösterilmiştir.

Tablo 6.Örgütsel Stres- İş Tatmini İlişkisinde Psikolojik Dayanıklılığın Dolaylı Etkisi

\begin{tabular}{llccc}
\hline \multicolumn{5}{c}{ \%95 Güven Aralığ1 } \\
\hline Dolaylı Etki Değeri (a.b) & S.H. & BootLLCI & BootULCI \\
\hline Psikolojik Dayanıklılık & $-0,5053$ & 0,0945 &,- 6880 &,- 3214 \\
\hline
\end{tabular}

Tablo 6'ya göre psikolojik dayanıklılığın iş tatmini üzerindeki dolaylı etkisinin anlamlı olduğu ve dolayısıyla da psikolojik dayanıklılığın örgütsel stres ile iş tatmini arasındaki ilişkiye (yüzdelik yöntem ile elde edilen Bootstrap alt ve üst güven aralığı değerleri 0 (sıfır) değerini kapsamadığ 1 için) aracılık ettiği tespit edilmiştir ( $b=-0,5053$; \% 95 CI [-.6880, -.3214]). Dolaylı etki değeri olan -0,5053 değeri, diğer çalışan kişiden örgütsel stres alg1 düzeyi 1 birim yüksek olan çalışanın (örgütsel stres düzeyi yüksek çalışanların psikolojik dayanıklılıklarının daha düşük olması ve psikolojik dayanıklılıkları daha yüksek olan çalışanların iş tatminlerinin daha yüksek olması nedeniyle) iş tatmin düzeyinin-0,5053 birim daha düşük olduğu şeklinde yorumlanmıştır.

Örgütsel stresin iş tatmini üzerindeki tam standardize etki büyüklüğünün derecesi Tablo 7'deverilmiştir.

Tablo 7. Aracılık Etkisinin Tam Standardize Etki Büyüklügü $\left(K^{2}\right)$

\begin{tabular}{|c|c|c|c|c|}
\hline \multicolumn{5}{|c|}{ \%95 Güven Aralığ } \\
\hline Psikolojik Dayanıklılık & S. & & BootLLCI & BootULCI \\
\hline $\begin{array}{l}\text { Tam Standardize } \\
\text { Etki Büyüklüğü }\end{array}$ & $-0,2252$ & 0,0440 &,- 3099 & -,1375 \\
\hline
\end{tabular}

Tablo 7' ye göre etki büyüklüğündeki güven aralıkları 0 (sıfır) değerini kapsamadığından anlamlıdır. Tam standardize etki büyüklüğü değeri -0,2252'dir. Gürbüz'e (2019: 64) göre $\mathrm{K}^{2}$ değeri ,01'e yakın ise düşük etki, $\mathrm{K}^{2}$ değeri 0 ,09'a yakın ise orta etki, $\mathrm{K}^{2}$ değeri 0,25 ' yakın ise yüksek etki şeklinde yorumlanır. $\mathrm{Bu}$ değerlere göre test ettiğimiz modeldeki aracılık etkisi yüksek değere yakındır.
$\mathrm{Bu}$ sonuçlar doğrultusunda araştırmanın 4 hipotezi de kabul edilmiştir. Analiz sonuçlarının araştırma modeli üzerindeki gösterimi Şekil 2'de verilmiştir.

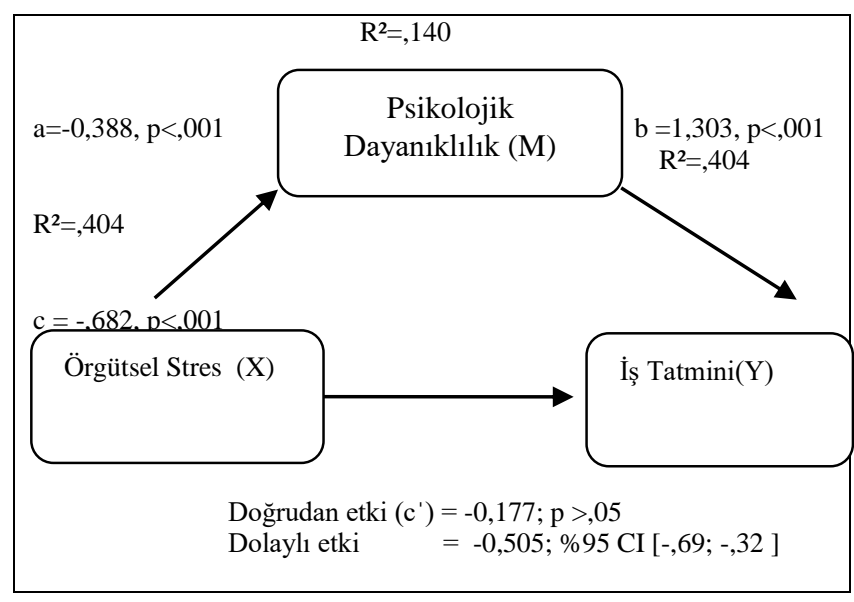

Şekil 2. Analiz Sonuçlarının Model Üzerinde Gösterimi

\section{Sonuçlar ve Tartışma}

$\mathrm{Bu}$ araştırmada örgütsel stresin akademisyenlerin iş tatmini üzerine etkisi ve bu etki üzerinde psikolojik dayanıklılığın aracı rolü araştırma kapsamında belirlenen 4 hipotezle belirlenmeye çalışılmıştır. $\mathrm{Bu}$ amaç doğrultusunda akademisyenlerden veriler toplanmıştır.

Örgütsel stresin iş tatminine etkisinin (c yolu=toplam etki) araştırıldığı analiz sonucunda anlamlı düzeyde negatif ilişki bulgulanmıştır. Örgütsel stres iş tatmini ilişkisi ile ilgili elde ettiğimiz sonuç geçmiş çalışmaların (Hollon ve Chesser, 1976; Tyson ve Aggarwal, 2002; Arslan, 2010; Ajayi ve Abimbola, 2013; Emiroğlu vd,2015; Kahraman, 2019) sonuçlarıyla paralellik göstermiştir. Örgütsel stresin psikolojik dayanıklılığa etkisinin (a yolu) araştırıldığı analiz sonucunda anlamlı düzeyde negatif ilişki bulgulanmıştır. Aracı değişken olan psikolojik dayanıklılığın iş tatminine etkisi (b yolu) istatistiksel olarak anlamlı ve olumlu yönde bulgulanmıştır. Örgütsel stresin psikolojik dayanıklılık ile birlikte regresyona dahil edildiği (c' yolu= doğrudan etki) zaman bulgulanan doğrudan etki değeri istatistiksel olarak anlamlı bulgulanmamıştır. $X^{\prime}$ in Y üzerindeki toplam etkisi anlamlı, M' nin Y üzerindeki etkisi anlamlı olmasına karşın $X$ ve $M$ birlikte regresyona dahil edilince ortaya çıkan doğrudan etki değeri anlamsızlaşmaktadır. Yapılan analizler sonucunda aracı değişken olan psikolojik dayanıklılığın olmadığı bir modelde örgütsel stresin iş tatmini üzerindeki (c yolu (toplam etki) $\left.=\mathrm{c}^{\prime}+\mathrm{ab}\right)$ etki değeri istatistiksel olarak anlamlı ve negatif yönde bulgulanmıştır. Son olarak psikolojik dayanıklılığın iş tatminine dolaylı etkisinin anlamlı olup olmadığının tespiti için yapılan analiz sonucunda psikolojik dayanıklılığın iş tatmini üzerindeki dolaylı etkisinin anlamlı olduğu ve dolayısıyla da psikolojik dayanıklılığın örgütsel stres ile iş tatmini arasındaki ilişkiye aracıllk ettiği tespit edilmiştir ve bu etkinin yüksek bir etki olduğu bulgulanmıştır.

Psikolojik dayanıklılık kavramının ortaya çıkış noktası bazı bireylerin stresten daha az etkilenmeleridir. Dolayısıyla psikolojik olarak dayanıklı olan çalışanların örgütsel stresten daha az etkilenmeleri ve iş tatmin seviyelerinin daha yüksek olması beklenilen bir sonuçtur. Bizim araştırma sonucumuzda bu iki beklenti desteklenmiş, psikolojik 
dayanıklılık- örgütsel stres arasında olumsuz ve psikolojik dayanıklılık iş tatmini arasında olumlu bir etkileşim ortaya koyulmuştur. Psikolojik dayanıklılık kavramı literatürde yeni olan bir kavram olması ve daha çok örgütsel bağlamda pozitif psikolojik sermayenin içinde incelenmesi nedeniyle çok fazla müstakil çalışmaya rastlanılmamıştır. Literatürde ayrıca örgütsel stres psikolojik dayanıklılık ilişkisini doğrudan araştıran çalışmaya da rastlanılmamıştır. Stres ile psikolojik dayanıklılık ilişkisinin bireysel bazda incelendiği hasta aileleriyle yapılan çalışmada (Yağmur ve Türkmen, 2017) stres düzeyi arttıkça psikolojik dayanıklılık düzeyinin azaldığı bulgulanmıştır. Psikolojik dayanıklılık ile ilgili çalışmalar genellikle yüksek ve devamlı stresin bir sonucu olan tükenmişlik (Çetin, Şeşen ve Basım, 2013; Bitmiş, Sökmen ve Turgut, 2013; Ocak ve Güler, 2017; Erdoğan ve İraz, 2019) konusunda yoğunlaşmış ve bu çalışmaların sonucunda genellikle iki kavram arasında negatif ilişki bulgulanmıştır. Psikolojik dayanıklılık iş tatmini ilişkisinin araştırıldığ Fındıklı, 2013; Akdemir ve Açan, 2017 sonuçları ise pozitif ilişki lehine olmuştur.

Son olarak bulgulanan sonuç psikolojik dayanıklılığın, örgütsel stres iş tatmini ilişkisinde güçlü bir aracılık etkisine sahip olduğudur. Örgütsel stres akademisyenlerin iş tatmin düzeylerini olumsuz etkilemekte bu durum üniversite yönetimini hem örgütsel stres hem de iş tatminsizliğinin ortaya çıkardığı olumsuzluklarla karşı karşıya bırakmaktadır. Bireylerde en fazla strese nedeni olarak karşımıza çıkan örgütsel stresin (Şimşek, vd., 2020: 109) neden olduğu olumsuz çıktılardan biri olan iş tatmini düşüklüğü örgütte çalışma koşullarının bozulduğunun en önemli işaretidir (Yılmazer, 2019:284). Dolayısıyla işyerlerinde örgütsel strese neden olan politik, yapısal ve fiziki nedenler düzeltildiği takdirde kişilerin hem iş hem de sosyal hayatlarına zarar veren stres olgusu kabul edilebilir düzeylere çekilebilecek ve iş tatmin düzeyleri de yükselecektir. Ancak bu çalışma ile ilgili bulgulanan en önemli sonuç örgütsel stres ve psikolojik dayanıklılığın birlikte regresyona dâhil edilmesiyle ortaya çıkan örgütsel stresin iş tatmini etkisini gösteren doğrudan etki değerinin istatistiksel olarak anlamsızlaşmasıdır. Yani örgüt yöneticileri çalışanların iş tatminini artırmak amacıyla sadece örgütsel stres faktörlerine müdahale etmemeli ayrıca psikolojik dayanıklılığı artırıcı uzman kişiler tarafından verilen eğitimlerle çalışana stresle mücadele yöntemlerini öğretmeye odaklanmalıdır. Böylece iş tatmininin yükseltilmesinde sorumluluk hem örgüt hem de çalışan tarafından üstlenilmiş olacaktır.

\section{Kaynakça}

Ajayi, M. P., \& Abimbola, O. H. (2013). Job satisfaction, organizational stress and employee performance: A study of NAPIMS. Ife PsychologIA: An International Journal, 21(2), S.75-82.

Akdemir, B., \& Açan, A. M. (2017). Psikolojik sermaye ve iş tatmini ilişkisini belirlemeye yönelik bir araştırma. Akademik Yaklaşımlar Dergisi, 8(2), 57-79.

Arslan, M. (2010). Çalışma yaşamında stresin iş tatmini üzerindeki etkisi ve bir araştırma. Yüksek Lisans Tezi,
Marmara Üniversitesi Sosyal Bilimler Enstitüsü, İstanbul.

Aytaç, S. (2009). İş stresi yönetimi el kitabı iş stresi: Oluşumu, nedenleri, başa çıkma yolları, yönetimi. Uludağ Üniversitesi İIBF, 1-34.

Aydın, Ş. (2004). Örgütsel stres yönetimi. Dokuz Eylül Üniversitesi, Sosyal Bilimler Enstitüsü Dergisi, 6 (3) 4974.

Basım, N. \& Şeşen, H. (2009). Örgütsel adalet algısı örgütsel vatandaşlık davranışı ilişkisinde iş tatmininin aracılık rolü. Ö. Torlak vd. (Editör) Osman Gazi Üniversitesi 17. Yönetim ve Organizasyon Kongresi Bildiriler Kitabı içinde (s. 808-814)

Basım, H. N., \& Çetin, F. (2011). Yetişkinler için psikolojik dayanıklılık ölçeği'nin güvenilirlik ve geçerlilik çalışması. Türk Psikiyatri Dergisi, 22(2), s.104-114.

Bingöl, D. (1997). Personel yönetimi. (3.bask1) İstanbul:Beta Basım Yayım Dağıtım.

Bitmiş, M., Sökmen, A., \& Turgut, H. (2013). Psikolojik dayanıklılığın tükenmişlik üzerine etkisi: örgütsel özdeşleşmenin aracılık rolü. Gazi Üniversitesi İktisadi ve Idari Bilimler Fakültesi Dergisi, 15(2), s.27-40

Bozgeyikli, H. (2012). Endüstri ve örgüt psikolojisinin kapsamı ve tarihi gelişimi. Hüseyin Izgar (Editör), Endüstri ve örgüt psikolojisi içinde (s.1-21). Konya: Eğitim Yayınevi.

Connor, K. M., \& Davidson, J. R. (2003). Development of a new resilience scale: The Connor-Davidson resilience scale (CD-RISC). Depression and Anxiety, 18(2), s.7682.

Çetin, F., \& Basım, H. N. (2011). Psikolojik dayanıklılığın iş tatmini ve örgütsel bağlılık tutumlarındaki rolü. $I s$, Guc: The Journal of Industrial Relations \& Human Resources, 13(3), s.79-94.

Çetin, F., Şeşen, H., \& Basım, H. N. (2013). Örgütsel psikolojik sermayenin tükenmişlik sürecine etkileri: Kamu sektöründe bir araştırma. Anadolu University Journal of Social Sciences, 13(3). s.95-107.

Emiroğlu, B. D., Akova, O., \& Tanrıverdi, H. (2015). The relationship between turnover intention and demographic factors in hotel businesses: A study at five star hotels in Istanbul. Procedia-Social and Behavioral Sciences, 207, S.385-397.

Erdoğan, P. \& İraz, R. (2019). Örgütsel vatandaşlık, örgütsel sinizm ve tükenmişliğe pozitif psikolojik sermaye etkisi. Konya: Eğitim Yayınevi.

Ergeneli, A. (2017). Örgütsel davranış örgüt ve birey. Ankara: Nobel Yayınevi

Erkuş, A., \& Fındıklı, M. A. (2013). Psikolojik sermayenin iş tatmini, iş performansı ve işten ayrılma niyeti üzerindeki etkisine yönelik bir araştırma. Istanbul University Journal of the School of Business Administration, 42(2), s.302-318.

Fletcher, D., \& Sarkar, M. (2013). Psychological resilience: A review and critique of definitions, concepts, and theory. European psychologist, 18(1), s.12. 
Gürbüz, S., \& Şahin, F. (2018). Sosyal bilimlerde araştırma yöntemleri. (5. Baskı) Ankara: Seçkin Yayıncılık.

Gürbüz, S. (2019). Sosyal bilimlerde arac1, düzenleyici ve durumsal etki analizleri. Ankara: Seçkin Yayıncılık.

Hollon, C. J., \& Chesser, R. J. (1976). The relationship of personal influence dissonance to job tension, satisfaction and involvement. Academy of Management Journal, 19(2), s.308-314.

https://learnersdictionary.com/definition/stress, E.T.01.09.2020

http://www.surveysystem.com/sscalc.html, E.T.01.09.2020

Işık, Ş. (2016). Psikolojik Dayanıklılık Ölçeği’nin geliştirilmesi: Geçerlik ve güvenirlik çalışması. The Journal of Happiness \& Well-Being, 4(2), 165-182.

Jackson, M., Ramsden, E., \& Cantor, D. (2014). Evaluating the role of Hans Selye in the modern history of stress. In Stress, shock, and adaptation in the twentieth century. University of Rochester Press.

Kahraman, O. (2019). Stres ile iş tatmini arasındaki ilişki: Milano'daki türk kobi yöneticileri üzerine bir araştırma, Yüksek Lisans Tezi, Harran Üniversitesi Sosyal Bilimler Enstitüsü, Şanlıurfa.

Kim, H. J., Tavitiyaman, P., \& Kim, W. G. (2009). The effect of management commitment to service on employee service behaviors: The mediating role of job satisfaction. Journal of Hospitality \& Tourism Research, 33(3), s.369-390.

Locke, E. A. (1969). What is job satisfaction?. Organizational behavior and human performance, 4(4), s.309-336.

Luthar, S. S., Cicchetti, D., \& Becker, B. (2000). The construct of resilience: A critical 15 evaluation and guidelines for future work. Child Development, 71, s.543-562

Luthans, F. (2002). The need for and meaning of positive organizational behavior. Journal Of Organizational Behavior, 23 (6), s.695-706.

Luthans, F., \& Youssef, C. M. (2004). Human, social, and now positive psychological capital management: Investing in people for competitive advantage. Organizational Dynamics: 33(2), 143-160.

Masten, A. S., Best, K. M., \& Garmezy, N. (1990). Resilience and development: Contributions from the study of children who overcome adversity. Development and psychopathology, 2(4), s.425-444.

Masten, A. S. (2001). Ordinary magic: Resilience processes in development. American 3 Psychologist, 56, s.227-238.
Mayordomo-Rodríguez, T., García-Massó, X., Sales-Galán, A., Meléndez-Moral, J. C., \& Serra-Añó, P. (2015). Resilience patterns: Improving stress adaptation based on an individual's personal features. The International Journal of Aging and Human Development, 80(4), s.316331.

Meredith, L. S., Sherbourne, C. D., Gaillot, S. J., Hansell, L., Ritschard, H. V., Parker, A. M., \& Wrenn, G. (2011). Promoting psychological resilience in the US military. Rand health quarterly, 1(2).

Ocak, M., \& Güler, M. (2017). Psikolojik sermayenin tükenmişlik üzerine etkisi: Görgül bir araştırma Erciyes Üniversitesi, Iktisadi ve Idari Bilimler Fakültesi Dergisi, (49), s.117-134.

Şimşek, M. Şerif, Çelik, A. \& Akgemci, T. (2019) Davranış bilimlerine giriş ve örgütlerde davranış. (10. Baskı) Konya: Eğitim Yayınevi

Şimşek, M.Ş., Çelik, A., Akgemci, T. \& Diken, A. (2020). Örgütsel Davranışv ve Yönetim Psikolojisi, Konya: Eğitim Yayınevi.

Turan Sarıkaya, İ. (2019). Psikolojik dayanıklılık düzeyi ile çatışma yönetimi stili arasındaki ilişki: beyaz yakalılar üzerine bir araştırma. (Yüksek Lisans Tezi). İstanbul Üniversitesi Sosyal Bilimler Enstitüsü, İstanbul.

Tyson, P. D., Pongruengphant, R., \& Aggarwal, B. (2002). Coping with organizational stress among hospital nurses in Southern Ontario. International journal of nursing studies, 39(4), S.453-459.

Urgan, S. \& Sevim, Ş. (2019). Uluslararası sağllk kuruluşlarında, sosyal sermaye ve pozitif psikolojik sermaye etkileşiminde kültürel zeka. Konya:Eğitim Yayınevi.

Yağmur, T., \& Türkmen, S. N. (2017). Ruhsal hastalığg olan hastalara bakım veren aile üyelerinde algılanan stres ve psikolojik dayanıklılık. Celal Bayar Üniversitesi Sağlık Bilimleri Enstitüsü Dergisi, 4(1), s.542-548.

Yılmazer, A. (2019). Stres ve stres yönetimi, Aydın Yılmazer (Editör), Davranış bilimlerine giriş ve örgütsel davranış içinde (s.197-209). Ankara: Detay Yayıncılık.

Yıldırım, Y., Taşmektepligil, M. Y., Üzüm, H. ve Bulut, D. (2011). Kısa versiyon Örgütsel Stres Ölçeğinin Türkçeye uyarlanması (geçerlilik ve güvenirlik çalışması). Selçuk Universitesi Beden Eğitimi ve Spor Bilimleri Dergisi, 13(1), s.103-108.

Zencirkıran, M., \& Keser, A. (2018). Örgütsel davranış, değerlemesi ve yönetimi. Bursa: Dora Basım Yayın.

Zhu, Y. (2013). A review of job satisfaction. Asian Social Science, 9(1), 293-298. 


\section{Extended Abstract}

The objective of this study is to determine the mediating role of resilience in the effect of organizational stress on job satisfaction. In addition, in the study, the effect of organizational stress on the psychological resilience and job satisfaction of academicians has been tried to be determined. For these purposes, the universe of this study consists of academicians working at a state university. The sample of the study consists of 261 academicians.

In the study, measurement tools whose validity and reliability have been tested in determining the organizational stress, psychological resilience and job satisfaction levels of academicians have been selected. The organizational stress scale used in the study was developed by Theorell et al. (1988) and adapted by Yildirim, Tasmektepligil and Uzum (2011), consists of 17 items and 4 dimensions. The job satisfaction scale used in the study is a one-dimensional, 5item, 5-point Likert-style scale adapted from Hackman and Oldhamn's (1975) job characteristics questionnaire by Basim and Sesen (2009). The Resilience Scale used in the study was developed by Isik (2016).

The $22^{\text {nd }}$ version of the SPSS program has been used in the analysis of the data obtained in the study. In order to reveal the validity and reliability of the scales, exploratory factor analysis and reliability analysis have been performed. The hypotheses of the research have been analyzed using the Process Macro (for SPSS) program developed by Hayes, and the Bootstrapping technique has been used to interpret the results obtained.

A significant negative relationship has been found as a result of the analysis investigating the effect of organizational stress on job satisfaction ( $\mathrm{c}$ path $=$ total effect). As a result of the analysis in which the effect of organizational stress on psychological resilience (a path) has been investigated, a significant negative relationship has been found. The effect of resilience, which is the mediator variable, on job satisfaction (b path) has been found statistically significant and positive. When organizational stress was included in regression with psychological resilience $(\mathrm{c}$ path $=$ direct effect), the detected direct effect value was not found to be statistically significant. Although the total effect of $\mathrm{X}$ on $\mathrm{Y}$ is significant, and the effect of $\mathrm{M}$ on $\mathrm{Y}$ is significant, the direct effect value that occurs when $\mathrm{X}$ and $\mathrm{M}$ are included in regression together becomes meaningless. As a result of the analysis, the effect value of organizational stress on job satisfaction $\left(\mathrm{c}\right.$ path $($ total effect $\left.)=c^{\prime}+a b\right)$ has been found to be statistically significant and negative in a model without psychological resilience whose mediator is variable. Finally, as a result of the analysis conducted to determine whether the indirect effect of psychological resilience on job satisfaction is significant, it has been found that the indirect effect of psychological resilience on job satisfaction is significant, and therefore, psychological resilience mediated the relationship between organizational stress and job satisfaction, and this effect has been found to be a high effect.

The emergence of the concept of resilience is that some individuals are less affected by stress. Therefore, it is an expected result that employees who are psychologically resilient are less affected by organizational stress and have higher job satisfaction levels. As a result of this study, these two expectations have been supported, and a positive interaction between psychological resilience and organizational stress and a positive interaction between psychological resilience and job satisfaction has been revealed. Another result found in the study is that psychological resilience has a strong mediating effect on the relationship between organizational stress and job satisfaction.

Organizational stress negatively affects the job satisfaction levels of academicians, and this situation exposes the university administration to the negativities caused by both organizational stress and job dissatisfaction. One of the negative outcomes of organizational stress (Simsek, et al., 2020: 109), which is the most important cause of stress in individuals, is low job satisfaction, which is the most important sign of the deterioration of working conditions in the organization (Yilmazer, 2019: 284). The most important result found in this study is that the direct effect value, which shows the effect of organizational stress on job satisfaction, caused by the incorporation of organizational stress and psychological resilience into regression together, is statistically insignificant. In other words, organizational managers should not only interfere with organizational stress factors in order to increase the job satisfaction of employees, but also should focus on teaching the employees methods of combating stress with the trainings given by experts who increase psychological resilience. Thus, the responsibility for increasing job satisfaction will be assumed by both the organization and the employee. 